\title{
SandyDuck'97 Nearshore Field Experiment Data Archive
}

\author{
Kent Hathaway \\ US Army Engineer Research and Development Center, Coastal and Hydraulics Laboratory \\ Field Research Facility \\ 1261 Duck Road, Kitty Hawk, NC 27949 \\ phone: 252-261-3511 fax: 252-261-4432 email: Kent.K.Hathaway@erdc.usace.army.mil \\ William Birkemeier \\ US Army Engineer Research and Development Center, Coastal and Hydraulics Laboratory \\ Field Research Facility \\ 1261 Duck Road, Kitty Hawk, NC 27949 \\ phone: 252-261-3511 fax: 252-261-4432 email: William.Birkemeier@erdc.usace.army.mi 1 \\ Award Numbers: N0001404MP20016 (US Army Corps of Engineers) \\ http://frf.usace.army.mil/SandyDuck/SandyDuck.stm
}

\section{LONG-TERM GOALS}

The long-term goal of this effort is to compile and distribute data collected during the SandyDuck'97 nearshore field experiment so that these data may be accessible by coastal researchers worldwide.

\section{OBJECTIVES}

Conducted in the fall of 1997, SandyDuck ' 97 was an intense, large-scale, investigation of surf zone winds, waves, currents, sediment transport, and morphology within a $1 \times 0.5 \mathrm{~km}$ region at the U.S. Army Corps of Engineers Field Research Facility (FRF) in Duck, North Carolina. SandyDuck and its predecessor DUCK94 (1994), were sponsored by the Office of Naval Research, the US Army Corps

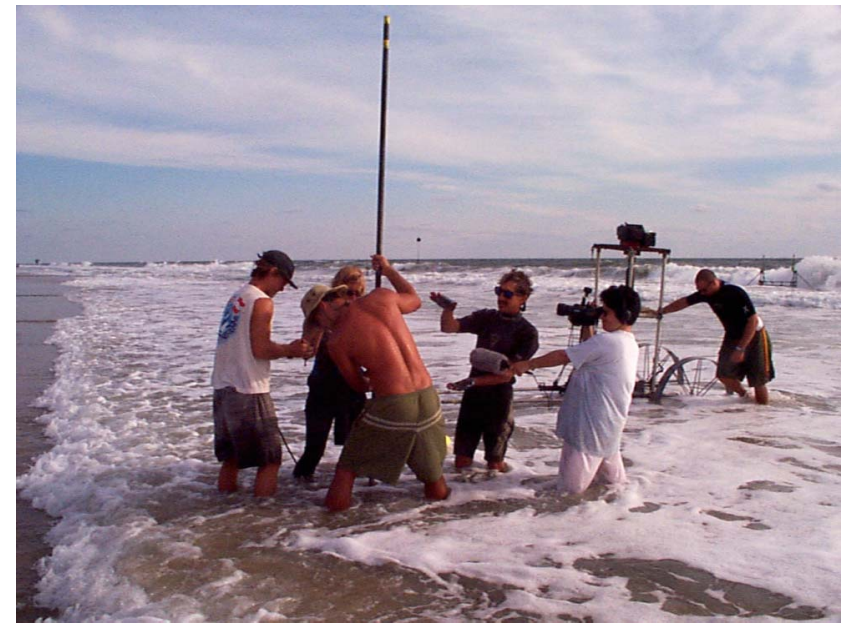

Figure 1. Instruments being deployed during SandyDuck of Engineers, and the US Geological Survey.

SandyDuck '97 experiment included 30 investigations of varying complexity, using a variety of instruments (Table 1, Figure 2). While the collected data were initially of interest to the participating investigators, they are also useful to a wide range of government, academic, and private researchers. By agreement it was resolved that experimenters' data would become publicly available three years after the experiment. The goal of this work was to compile the most important SandyDuck '97 geophysical nearshore process data into a single coherent data set, and to make the data publicly available via the web for broad usage by those interested in physical processes in the littoral zone. The SandyDuck '97 data set will be added to the DUCK94 data ( http://dksrv.usace.army.mil/jg/dk94dir ), and the 1990 DELILAH experiment data ( http://dksrv.usace.army.mil/jg/del90dir ). 


\section{Report Documentation Page}

Form Approved

OMB No. 0704-0188

Public reporting burden for the collection of information is estimated to average 1 hour per response, including the time for reviewing instructions, searching existing data sources, gathering and maintaining the data needed, and completing and reviewing the collection of information. Send comments regarding this burden estimate or any other aspect of this collection of information,

including suggestions for reducing this burden, to Washington Headquarters Services, Directorate for Information Operations and Reports, 1215 Jefferson Davis Highway, Suite 1204, Arlington

VA 22202-4302. Respondents should be aware that notwithstanding any other provision of law, no person shall be subject to a penalty for failing to comply with a collection of information if it

does not display a currently valid OMB control number.

1. REPORT DATE

30 SEP 2004

4. TITLE AND SUBTITLE

SandyDuck-97 Nearshore Field Experiment Data Archive

6. $\operatorname{AUTHOR}(\mathrm{S})$

7. PERFORMING ORGANIZATION NAME(S) AND ADDRESS(ES)

US Army Engineer Research and Development Center,,Coastal and Hydraulics Laboratory Field Research Facility,,1261 Duck Road,Kitty

Hawk,,NC,27949

9. SPONSORING/MONITORING AGENCY NAME(S) AND ADDRESS(ES)
3. DATES COVERED

00-00-2004 to 00-00-2004

5a. CONTRACT NUMBER

5b. GRANT NUMBER

5c. PROGRAM ELEMENT NUMBER

5d. PROJECT NUMBER

5e. TASK NUMBER

5f. WORK UNIT NUMBER

8. PERFORMING ORGANIZATION

REPORT NUMBER

10. SPONSOR/MONITOR'S ACRONYM(S)

11. SPONSOR/MONITOR'S REPORT NUMBER(S)

12. DISTRIBUTION/AVAILABILITY STATEMENT

Approved for public release; distribution unlimited

13. SUPPLEMENTARY NOTES

14. ABSTRACT

15. SUBJECT TERMS

16. SECURITY CLASSIFICATION OF:

a. REPORT

b. ABSTRACT

unclassified

unclassified

c. THIS PAGE

unclassified

17. LIMITATION OF ABSTRACT

Same as

Report (SAR)
18. NUMBER 19a. NAME OF

OF PAGES RESPONSIBLE PERSON

6 


\begin{tabular}{|c|c|c|c|c|c|c|c|c|c|}
\hline \multicolumn{3}{|c|}{ SandyDuck Experiments } & \multirow{2}{*}{ 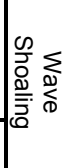 } & \multirow{2}{*}{ 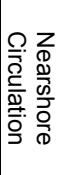 } & \multirow{2}{*}{ 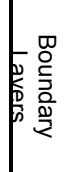 } & \multirow{2}{*}{ 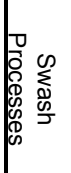 } & \multirow{2}{*}{ 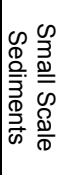 } & \multirow{2}{*}{ 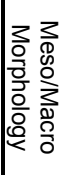 } & \multirow{2}{*}{ 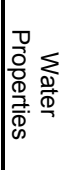 } \\
\hline No. & Investigators & Experiment Title & & & & & & & \\
\hline $1^{*}$ & $\begin{array}{l}\text { Beach, Holman, Sternberg, } \\
\text { Ogston, Conley }\end{array}$ & Fluid-sediment interactions in the surf zone & & $\mathbf{x}$ & $\mathbf{x}$ & & $\mathbf{x}$ & & \\
\hline 2 & Drake, Snyder & $\begin{array}{l}\text { Side-scan sonar studies of nearshore } \\
\text { morphology in the vicinity of Duck, NC }\end{array}$ & & & & & & $\mathbf{X}$ & \\
\hline 3 & Dugan & $\begin{array}{l}\text { Nearshore measurements for long-range } \\
\text { remote sensing }\end{array}$ & & $\mathbf{x}$ & & & & $\mathbf{x}$ & \\
\hline 4 & Edson & $\begin{array}{l}\text { Application of a marine surface layer model } \\
\text { to the Coastal Environment }\end{array}$ & & & $\mathbf{x}$ & & & & \\
\hline $5^{*}$ & $\begin{array}{l}\text { Elgar , Herbers, O'Reilly, } \\
\text { Guza }\end{array}$ & Surf zone waves currents and morphology & $\mathbf{x}$ & $\mathbf{x}$ & & $\mathbf{x}$ & & $\mathbf{x}$ & \\
\hline $6^{*}$ & $\begin{array}{l}\text { Friedrichs, Brubaker, Wright, } \\
\text { Vincent }\end{array}$ & $\begin{array}{l}\text { Cross-shoreface suspended sediment: a } \\
\text { response to the intersection of nearshore and } \\
\text { shelf processes }\end{array}$ & & $\mathrm{X}$ & $\mathrm{X}$ & & $\mathrm{X}$ & & \\
\hline 7 & $\begin{array}{l}\text { Haines, Gelfenbaum, } \\
\text { Wilson }\end{array}$ & Vertical structure, bedforms, turbulence & & $\mathrm{x}$ & $x$ & & $x$ & & \\
\hline $8^{*}$ & Hanes,Vincent & Near bed intermittent suspension & & $\mathbf{X}$ & & & $\mathbf{x}$ & & \\
\hline $9 *$ & Hay, Bowen, Doering, Zedel & $\begin{array}{l}\text { Nearshore sediment dynamics: suspension, } \\
\text { bedforms, and bubbles }\end{array}$ & & $\mathbf{x}$ & $\mathbf{x}$ & & $\mathbf{x}$ & & $\mathbf{x}$ \\
\hline 10 & Heitmeyer & Surf-noise experiment & & & & & & & $\mathbf{x}$ \\
\hline 11 & Herbers, O'Reilly, Guza & $\begin{array}{l}\text { Wave propagation across the continental } \\
\text { shelf }\end{array}$ & $\mathbf{x}$ & & & & & & \\
\hline 12 & Holland, Sallenger & Swash zone morphology & & & & $\mathbf{x}$ & & & \\
\hline 13 & Holman & Large scale morphology & & & & & & $\mathbf{x}$ & \\
\hline $14^{*}$ & Howd, Beavers & $\begin{array}{l}\text { Geologic signature of storm events on the inner } \\
\text { continental shelf and outer surf zone }\end{array}$ & & & & & & $x$ & \\
\hline $15^{*}$ & Howd, Hathaway & Shoreface processes and bed response & $\mathbf{x}$ & $\mathbf{X}$ & & & & $\mathbf{x}$ & \\
\hline 16 & Jensen & Evolution of wave spectra in shallow water & $x$ & & & & & & \\
\hline 17 & Jol & Ground penetrating radar of the beach & & & & & & $X$ & \\
\hline 18 & Lippmann & $\begin{array}{l}\text { Observations of nearshore wave breaking, } \\
\text { whitecapping, and large scale sand bar } \\
\text { morphology }\end{array}$ & $\mathbf{x}$ & & $\mathbf{x}$ & & & & \\
\hline $19^{*}$ & List & Regional shoreline change & & & & & & $\mathrm{X}$ & \\
\hline $20^{*}$ & Long & $\begin{array}{l}\text { Wind wave frequency-direction spectral } \\
\text { measurements }\end{array}$ & $\mathrm{x}$ & & & & & & \\
\hline $21^{*}$ & Miller, Resio & Sediment transport rates during storms & & $\mathrm{X}$ & $\mathrm{X}$ & & $\mathrm{x}$ & & \\
\hline 22 & Sallenger & $\begin{array}{l}\text { Coastal applications of scanning airborne laser } \\
\text { (LIDAR) }\end{array}$ & & & & & & $\mathrm{X}$ & \\
\hline $23^{*}$ & Smith & $\begin{array}{c}\text { Observations of waves and currents near the } \\
\text { surf zone }\end{array}$ & $\mathbf{x}$ & $\mathbf{x}$ & & & & & \\
\hline 24 & Su, Teague & $\begin{array}{c}\text { Coastal breaking wave and bubble } \\
\text { measurements }\end{array}$ & & & & & & & $\mathbf{X}$ \\
\hline 25 & Svendsen, Grosskopf & Models of nearshore circulation & $\mathbf{X}$ & $\mathbf{X}$ & & & & & \\
\hline 26 & Thornton, Stanton & Nearshore wave \& sediment processes & $\mathbf{x}$ & $\mathbf{x}$ & $\mathbf{x}$ & & $\mathbf{x}$ & & \\
\hline 27 & Trizna, Kirby & $\begin{array}{l}\text { Experimental tests of Boussinesq wave } \\
\text { models in the near surf zone }\end{array}$ & $\mathbf{x}$ & $\mathbf{x}$ & & & & & \\
\hline 28 & Trizna & $\begin{array}{l}\text { Marine radar remote sensing of bar \& rip } \\
\text { morphology }\end{array}$ & & & & & & $\mathbf{x}$ & \\
\hline 29 & Trowbridge & $\begin{array}{l}\text { Measurement of bottom stress in the wind- } \\
\text { and wave-forced nearshore environment }\end{array}$ & $\mathbf{x}$ & $\mathbf{x}$ & $\mathbf{x}$ & & & & \\
\hline 30 & Wu, Shih, Kobayashi & Nearshore water level profiles during storms & $\mathrm{X}$ & & & & & & $\mathrm{X}$ \\
\hline
\end{tabular}

Table 1. SandyDuck Experiments. ONR projects (partial or fully funded) are in bold. Experiment numbers with an asterisk have sent data for the server/archive. 


\section{SandyDuck '97 Surf Zone Instrument Layout}

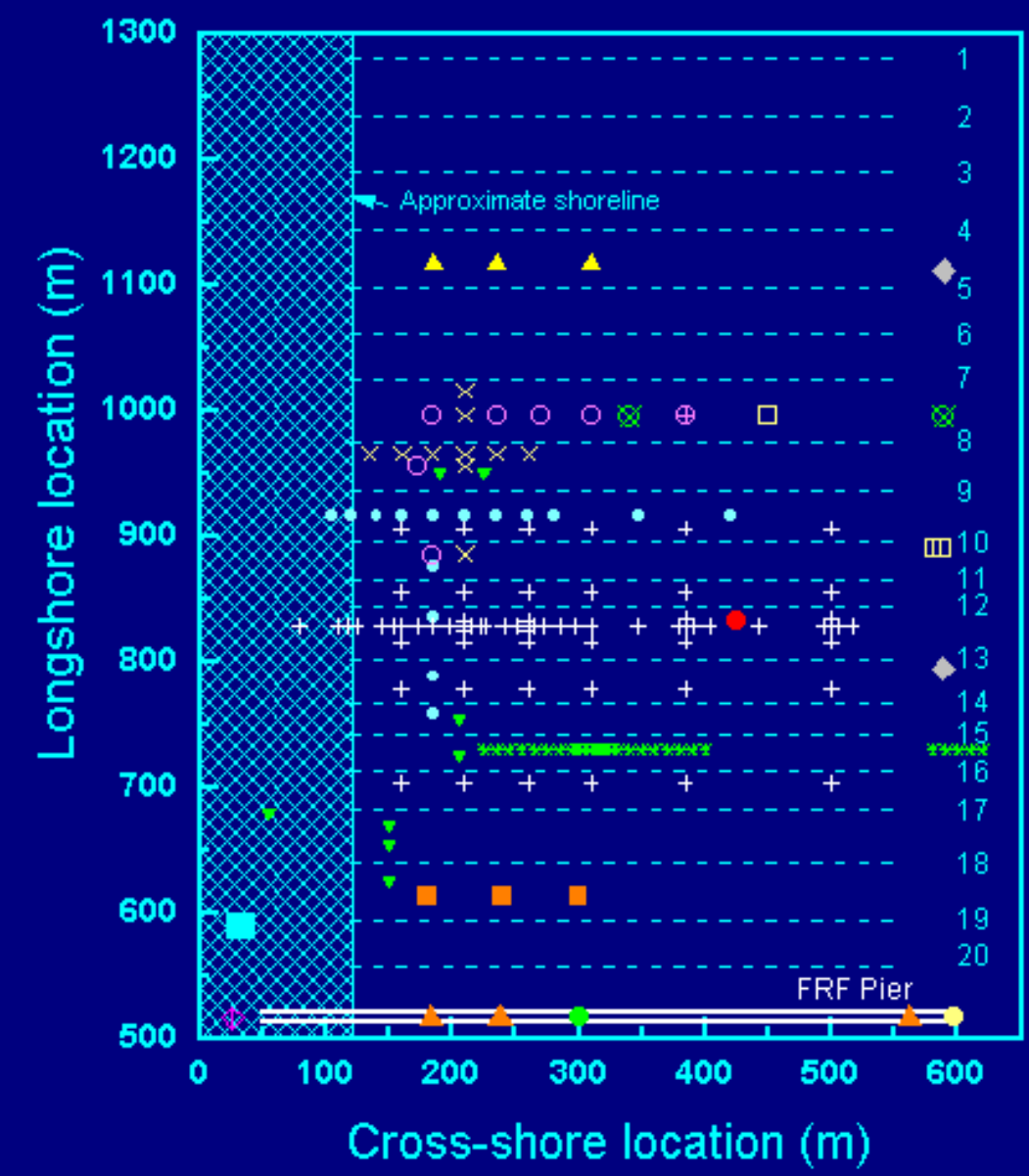

Investigator/Experiment

- Thornton, Stanton

+ Elgar, Herbers, O'Reilly, Guza

$\times$ Beach, Holman, Sternberg,

Ogston, Conley

Hay, Bowen, Doering, Zedel

$\oplus$ Hanes, Vincent

\& Haines, Gelfenbaum, Wilson

- Su, Teague

* Heitmeyer

- Svendsen, Grosskopf

Trowbridge

- Lippmann

口 Howd, Hathaway

- Resio, Miller

$\bowtie$ Trizna

A Wu, Shih, Kobayashi

- Smith

- Edson

- FRF Tower

Survey lines and numbers

Figure 2. Instrumentation layout for 18 experiments during SandyDuck'97. Twenty cross-shore survey locations are indicated with dashed lines.

\section{APPROACH}

The SandyDuck data include a wide variety of data types stored by the individual investigators in many different formats on a network of widely distributed computers and media. Because of this and to make the data widely available, we adopted and adapted a UNIX/web based data management system originally developed for the Joint Global Ocean Flux Study (JGOFS). It has several features that made it desirable for this application.

Even though the JGOFS server was designed for serving distributed data sets it was decided for practical purposes, to use a single server for the data. This alleviated requiring multiple investigators to maintain web servers for access to their data, and insured that the data remain online, even as interest by the collecting investigators wanes. The original data were translated into a common format, columnar ASCII files which are MATLAB and spreadsheet compatible, making them easy to use by all users. Times were adjusted to Eastern Standard Time and units were converted to MKS. Identical 
formats have been used for similar data types collected by different investigators (mean current statistics, wave height measurements, etc.). Several data sets are also provided in MATLAB "mat" files for direct loading onto any platform running MATLAB.

Some data were not compatible with the data server and are handled by other web tools such as FTP and HTML pages. In particular the "raw" binary time series sampled from single-channel sensors (current component, pressure, optical backscatterance, sonic altimetry, temperature, wind speed, wind direction, etc.), could not be efficiently delivered with a columnar ASCII format but are available with FTP in organized directory structures with associated metadata. Digital image data (camera snapshots, time-averaged images, movie loops of various processes) are delivered with static web pages and FTP

\section{WORK COMPLETED}

The SandyDuck '97 data can be found at http://dksrv.usace.army.mil/jg/sd97dir (Figure 3). This is the web page for the data server, and has links to the other Duck data sets as well as to the experiment home pages that contain summaries and documentation on each experiment. Data from the DELILAH 1990 and DUCK94 nearshore experiments were added to the data server in FY01, complete with a data report (PDF and HTML formats), statistics, binary time series, and extensive documentation on data quality and analysis methods (metadata). There are presently 74 GB of experiment data on the server with about $120 \mathrm{~GB}$ of raw binary timeseries which will be added when a larger server is put online in November 2004. The entire archive was also duplicated on CD and DVD for offsite storage.

The SandyDuck Archive includes the most important and generally useful data sets, those that monitored surf zone dynamics, circulation, and beach response. However, delays in receiving data from some SandyDuck PI's resulted in their data not being included (see table). Although ONR funding for this activity ends in FY04 the US Army Corps of Engineer's Field Research Facility will continue to maintain the server and add data sets should they ever be received.

\section{RESULTS}

The data server has proven to be an efficient means to deliver SandyDuck ' 97 processed data, raw data, and metadata. Over $45 \mathrm{~GB}$ of data has been transferred in the past two years. Monthly web statistics are now available online (see http://dksrv.usace.army.mil/cgi-bin/webstats.pl). Feedback on the server $=\mathrm{s}$ data accessibility and presentation are requested and will be used in future refinements.

\section{IMPACT/APPLICATIONS}

By making SandyDuck data available to researchers worldwide it will hopefully achieve maximum utilization and permanence. In addition to making these data sets available to other researchers, the archive also provides high quality data for students working on Masters or PhD degrees. Based on the amount and success of research accomplished following earlier FRF experiments, the more comprehensive SandyDuck data will have wide use and great potential for advancing nearshore science. 


\section{RELATED PROJECTS}

We plan to continue this effort with support of the FRF Measurements Program with the objectives of adopting common formates (NetCDF) and linking this archive to the potentially more powerful Distributed Ocean Data System (DODS) for improved availability and distribution.

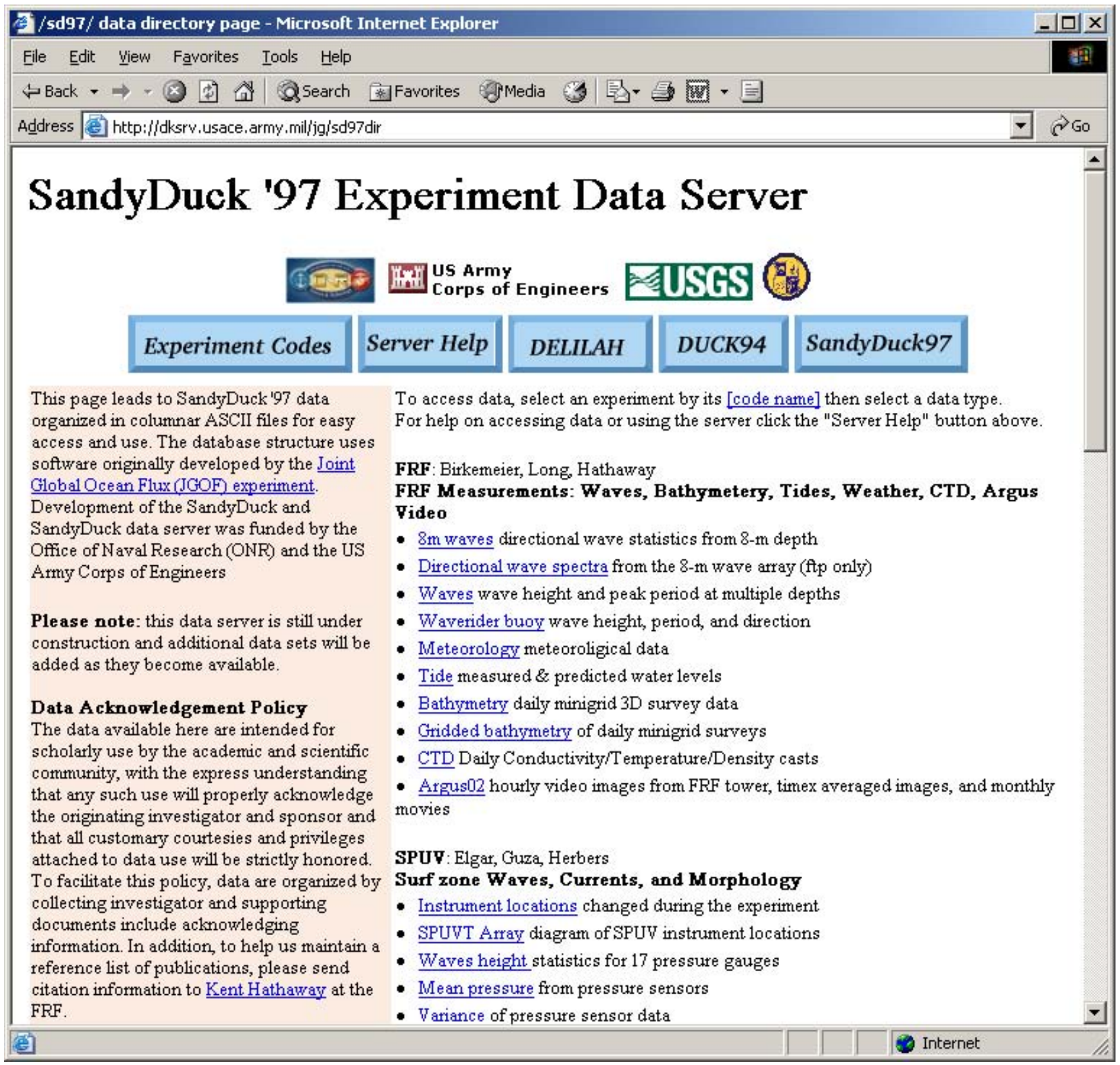

Figure 2. SandyDuck'97 data server home page showing funding agencies and links to a variety of data sets from the most significant SandyDuck'97 experiments. The page includes links to DELILAH, DUCK94, and SandyDuck'97 home pages. 